\title{
NEW NEARCTIC MECOPTERA, WITH NOTES ON OTHER SPECIES
}

\author{
By F. M. CARPENTER \\ Museum of Comparative Zoölogy, Harvard University
}

During the three years subsequent to the publication of my revision of the Nearctic Mecoptera ${ }^{1}$, a number of new and interesting species have come to my attention. Some of these were taken by me in the central and western states, but by far the majority were received from other entomologists, as follows: Mr. E. S. Thomas, Ohio State Museum; Mr. C. A. Frost, Framingham, Mass.; Dr. C. B. Philip, Hamilton, Montana; Dr. H. B. Mills, Yellowstone National Park, Wyoming; Mr. E. P. Van Duzee, California Academy of Sciences; Mr. L. C. Lloyd, Seattle, Washington; Dr. H. H. Ross, Illinois State Museum, Urbana, Illinois; Dr. Hugo Kahl, Carnegie Museum, Pittsburg; and Dr. C. E. Mickel, University of Minnesota. To all these I am grateful for their coöperation.

In the present paper I have included the most interesting of the new locality records and descriptions of eight new species. Including the latter, the total number of Nearctic species is sixty-four.

\section{Family Panorpidæ \\ Brachypanorpa montana Carp.}

Bull. Mus. Comp. Zoöl., 72 (6) : 212; 1931.

Four males were taken among pines at Crater Lake, Oregon, July 16, 1932, at an altitude of about 8,000 feet (F. M. Carpenter). As far as I am aware, these are the only specimens in addition to the types which have been collected. No females were found in spite of careful searching.

Panorpa lugubris Swederus

Kgl. Svenska Vetensk.-Akad. Nya Handl., 8:279, 1787.

In the collection of the Illinois State Museum there is a

1 Bull. Mus. Comp. Zool., 72 (6) : 205-277, pls. 1-8, 1931.

See also Bull. Brooklyn Ent. Soc. 27: 149-151. 1932. 
specimen of this species labeled "N. Mex.". Since lugubris has previously been reported only from the Carolinas, Georgia, Florida and Alabama, a New Mexico record is most surprising. Dr. Ross, of the Illinois Museum, assures me, however, that the locality datum is almost certainly correct. If so, this specimen extends by some three hundred miles (to about longitude $103^{\circ}$ ) the westward range of Panorpa in the Nearctic region, for I have seen no previous records of the genus beyond Austin, Texas (longitude $98^{\circ}$ ).

Panorpa insolens, n. sp. (Figure 5.)

Body: light reddish-brown. Fore wing: length $12 \mathrm{~mm}$; width $3 \mathrm{~mm}$., membrane faintly yellow, markings grayishbrown; apical and pterostigmal bands entire; basal band broken at the middle, but very broad, both upper and lower portions fusing with the first basal spot; second basal spot very small; both marginal spots absent; cross veins not margined. \& genitalia: internal skeleton small, the axis entirely confined to the plate, not projecting anteriorly as in most species of the genus. Male unknown.

Holotype: Cincinnati, Ohio; May 30, 1908; in Museum of Comparative Zoölogy.

Although in describing this species from the female alone, I have departed from my usual policy of not establishing a new species of Panorpa unless the male is known, I consider the wing markings of this particular insect so unusual that the male when found will at once be recognized. In none of the other Nearctic Mecoptera has the basal band been modified to anything like the form in insolens. The internal skeleton is close to that of $P$. carolinensis Banks, and I suspect that the male when found will have a genital structure also close to that of carolinensis. In my key to the females of Panorpa (1931, p. 224) insolens runs to section 9, including signifer, carolinensis and longicornis, from all of which it can be readily separated by the form of the basal band of the fore wing.

Panorpa virginica Banks

Psyche, 13 : $99 ; 1906$.

Two males in the Illinois State Museum are labeled "Wisconsin," the first record of the species in that state. 


\section{Panorpa isolata Carp.}

Bull. Mus. Comp Zoöl., 72 : 241; 1931.

One male from Waukegan, Illinois, July 7, 1932 (T. H. Frison) is in the Illinois State Museum. Since this species has not previously been found outside of Georgia, the Carolinas and Tennessee, the Illinois record is most interesting and unexpected; it probably signifies that the species occurs in Kentucky and Ohio.

Panorpa speciosa Carp. (Figure 4.).

Bull. Mus. Comp. Zoöl., 72 : 243, 1931.

During the summer of 1934 I was fortunate enough to secure two males and a female of this rare species, which has previously been known only from four males. Both were taken at Vandalia, Illinois, June 28, 1934. The female is similar to the male in coloration and wing markings. The internal skeleton (figure 4) is small but has a very deep "U"-shaped cleft; the axis is small, projecting only a short distance beyond the plate itself; there is a small chitinous envelope covering a part of the axis and surrounding part of the plate. This female, now in the Museum of Comparative Zoölogy, is designated as the allotype.

Panorpa bifida, n. sp. (Figures 1, 3.)

Body brown to yellow; anal horn present. Fore wing: length 11-13 mm.; width, 3-4 mm.; membrane faintly yellow, markings dark-brown or black; apical band entire; pterostigmal band broken at middle; basal band interrupted; first basal and first and second marginal spots present; second basal spot absent; cross veins margined. $\hat{s}$ genitalia: genital bulb rounded; forceps of moderate size, the distal half quite slender; hypovalves long, extending very nearly to the base of the forceps; ventral valves elaborate, each consisting of a single semi-circular basal piece which forks distally into two long branches; the outer one of these is the longer, is slightly curved, and bears a number of barbs; the inner branch is nearly straight and is also barbed. o genitalia: internal skeleton small; the posterior part of plate in the form of a half-moon; the anterior part with a deep, broad "U"-shaped incision. 
Holotype ( $\delta$ ) : Rector, Penna., July 18, 1921 ; in the Carnegie Museum, Pittsburg, Pennsylvania.

Allotype: same locality and date as holotype; in the Carnegie Museum, Pittsburg, Pennsylvania.

Paratypes: 1 ô, Rector, Pennsylvania, July 31, 1921; 1 \&, Allegheny Co., Pennsylvania, July; in the Museum of Comparative Zoölogy.

This unusual Panorpa is closest to anomala Carp. in both wing markings and genitalia. The male genital bulb of bifida, however, has longer forceps and hypovalvæ, and the shape and lengths of the ventral valves are very different. The internal skeleton of the female genitalia has a much broader incision posteriorly than that of anomala. In my key to the males of Nearctic Mecoptera (Bull. Mus. Comp. Zoöl., $72(6), 1931)$ bifida runs to the couplet containing dissimilis and decorata (28), from both of which it can readily be separated by the forked ventral valves. The female runs to the last group of species under number 22 and can be distinguished from the species included there only by the structure of the internal skeleton.

\section{Panorpa flexa, n. sp. (Figure 2.)}

Head, thorax and first 6 segments of abdomen darkbrown, nearly black; abdominal segments 7-9 yellowishbrown; anal horn absent. Fore wing: length, $11 \mathrm{~mm}$. width, $3 \mathrm{~mm}$.; membrane colorless, markings light brown, all bands interrupted; both marginal and both basal spots absent, cross veins margined. of genitalia: genital bulb rather slender, forceps of moderate size, without lobes; a cluster of heavy, black hairs at base of forceps; hypovalves long, almost reaching to the base of the forceps; ventral valves consisting of a long, cylindrical, glaborous shaft, smoothly curved; at the base of this shaft is a cluster of 5 radiating barbs; an abruptly tapered point terminates the shaft itself. Female unknown.

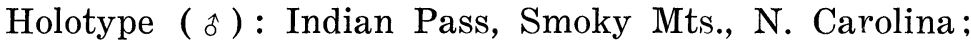
September 4, 1933 (C. F. Walker) ; in the Museum of Comparative Zoölogy.

This locality is almost identical with that at which the types of $P$. longicornis and many other Panorpas were col- 
lected by the writer at the same season three years previous. Although no specimens of flexa were among the several hundred Panorpas which were secured at that time, the specimen described was the only Panorpa which Mr. Walker collected in the vicinity.

Since flexa does not possess the anal horn, it falls into the nebulosa group of Panorpa, and in my key (1931, p. 222) runs to couplet 7 . As this couplet reads, flexa will not be covered by either choice; but if the first line of the couplet be changed to "ventral valves curved," both flexa and sigmoides will be included. From sigmoides the new species can be distinguished by the shape of the ventral valves, which are sigmoidally curved in sigmoides but nearly semicircular in flexa.

\section{Panorpa latipennis Hine}

Bull. Sci. Lab., Den. Univ., 11 : 248, 1901.

Two females received from E. S. Thomas, of the Ohio State Museum, were collected in Ohio: Fallsburg, June 18, 1932 (C. F. Walker), and Bay Point, Ottawa County, July 18,1931 . These are the first records in the state and bear out my previous suggestion (1932) that latipennis probably occurred in Ohio and Pennsylvania.

Panorpa submaculosa Carp.

Bull. Mus. Comp. Zoöl., 72 (6) : 255; 1931.

One female was taken by C. E. Mickel in Prince George Co., Maryland, July 27, 1929; this constitutes the first record for the state.

Family Bittacidæ

\section{Bittacus punctiger Westwood}

Trans. Ent. Soc. Lon., 4:195; 1841.

One male, now in the Museum of Comparative Zoölogy, was collected at Dunedin, Florida, during March (Blatchley) ; this constitutes the first record in that state, although the species has previously turned up in neighboring states.

Family Boreidæ

During the past two years several extensive collections of Boreus, mostly from western states, have been received for 
determination. One very unusual species (reductus) from this lot has already been described ${ }^{2}$. Quite recently, also, Mr. L. C. Lloyd has described ${ }^{3}$ another species (intermedius) from Alaska, and recorded the occurrence of B. unicolor at the same locality. Through the courtesy of Mr. Lloyd and the authorities of the Washington State Museum, these specimens were sent to me for examination. Much to my surprise, a study of all the Boreus material now at hand reveals that among the recently collected Western material there are no less than five undescribed species, making a total of twelve species of the genus now known from the Nearctic region.

These additional species have brought to light several new characteristics which are most useful in the taxonomy of at least the Nearctic members of Boreus. The most important of these is the form of the hypandrium (tenth sternite), which may be either narrowly or broadly triangular, and may be either emarginate (notched) or entire (straight). Since the shape of the hypandrium is very helpful in the identification of the new species described below, I have also included here figures or descriptions of other Nearctic species of the genus. Some of the new species are also characterized by the color and length of the pubescence, features which show very little difference among the previously described ones. The lengths of the rostrum and ovipositor are likewise convenient diagnostic characteristics, but I have found it advisable to measure these at somewhat different positions from formerly. In the present descriptions the rostrum is measured from the ventral edge of the eye, and the ovipositor from the posterior margin of the ninth tergite 4 . This gives a slightly smaller dimension for the length of the ovipositor than when it is measured from the corresponding sternite, but the measurement is more easily obtained since the specimens are usually glued to points and the ventral surface of the head thus concealed. The detailed coloring of the various parts of the body, as I have already pointed

2 Can. Ent., 65 : 94-95. 1932.

3 Pan. Pacific Ent., 10: 119-120. 1934.

4 the ninth tergite because the tenth is modified to form a long sheath covering the ovipositor proper. 
out, is of little taxonomic value, because it is subject to much individual variation.

Since there are now more than twice as many species of Boreus as were known when my key was published (1931), new keys to both sexes are included here.

\section{Key to Males of Boreus}

1. Hypandrium entire

Hypandrium emarginate

8.

2. Wings and all of body black

3.

Wings brown or yellow

4.

3. Body covered with long, white pilosity; hypandrium slenderly triangular reductus Carp. Body covered with very fine, white pubescence, hypandrium broadly triangular unicolor Hine.

4. Fore wings gradually tapering throughout their entire lengths

5.

Fore wings strongly narrowed in proximal half 6 .

5. Fore wings very broad and long, two and one-half times the length of the rostrum (British Columbia)

elegans n. sp.

Fore wings not so broad and of moderate length, only one and one-half times the length of the beak (eastern United States) nivoriundus Fitch.

6. Distal half of wings very slender; rostrum twice the length of the eye intermedius Lloyd. Distal half of wing normally slender; rostrum only one and one-half times the length of the eye $\quad 7$.

7. Body except wings black or nearly so

8.

Body brown or reddish brown californicus var. californicus Packard.

8. Wings yellow-brown borealis Banks. Wings dark brown californicus var. fuscus n. var.

9. Body covered with long white or yellowish pilosity 10 . Body covered with very fine white pilosity

11.

10. Wings and body deep black Wings yellow or light brown, body dark brown nix n. sp. pilosus $\mathrm{n} . \mathrm{sp}$.

11. Wings yellowish-brown, much lighter than the dark brown body isolatus n. sp. 
Wings either black or brown, always the same color as the body brumalis Fitch.

Key to Females of Boreus

1. Fore wing reduced to a minute scar, similar to that of the hind wing reductus Carp. Fore wing in the form of a small oval pad 2.

2. Wings and body the same color (brown or black) 3 . Wings much lighter (yellow or yellow-brown) than body (dark brown or black)

3. Ovipositor short, only as long as rostrum. Ovipositor distinctly longer than rostrum

4. Body either black or very dark brown brumalis Fitch. Body light brown or medium brown nivoriundus Fitch.

5. Body covered with long, white or yellowish hairs nix n. sp.

Body covered with fine, white pubescence

6.

6. Ovipositer twice as long as rostrum unicolor Hine. Ovipositer only one and one-half times as long as rostrum

7. Ovipositer twice the length of the rostrum gracilis $\mathrm{n}$. sp. intermedius Lloyd. Ovipositer at most one and one-half times as long as the rostrum

8. Body light brown or reddish brown

californicus var. californicus Packard. Body black or nearly so

9.

9. Body black, with a pronounced bronze hue; abdomen above exceedingly shiny borealis Banks. Body jet black; abdomen above with only a slight shine californicus fuscus, $\mathrm{n}$. var.

\section{Boreus brumalis Fitch}

Amer. Journ. Agric., 5 : 278; 1847.

Although this species has previously been known to occur only in Massachusetts, New York, District of Columbia and Michigan (Detroit), a great many specimens have been taken in Hocking and Fairfield Counties, Ohio, December 5-25, 1933 (E. S. Thomas, J. S. Thomas, W. Goslin, R. Goslin). These Ohio specimens, although somewhat smaller and more 
uniformly black than the New England specimens, show no structural differences whatever. The posterior margin of the hypandrium is emarginate, the hypandium as a whole being shaped much like that of isolatus, n. sp. (figure 11). The body of brumalis is covered with a prominent yellow pubescence, which is more striking in the black specimens than in the brown ones.

\section{Boreus nivoriundus Fitch}

Amer. Journ. Agric., 5 : 277; 1847.

This is another species which, previously known only from New England and northern New York, has been found in Hocking and Fairfield Counties by the above-named collectors (December 5-25, 1934). The Ohio specimens, like those of brumalis, are very much smaller than the more eastern ones, being about one-half the length of the latter. In all other respects, however, the Ohio specimens and the New England ones are identical. The fact that the more southern specimens of both brumalis and nivoriundus are decidedly smaller than the northern ones suggests that the more moderate climatic conditions tend to cause smaller specimens in this particular genus of insects, which are of course only active in the adult stages from November to February.

The hypandrium of nivoriundus is entire and shaped very much like that of unicolor (figure 15). The color of the body is subject to some variation, the New England specimens being light brown and the Ohio ones somewhat darker, but the color never reaches the blackish brown of brumalis.

\section{Boreus unicolor Hine (Figure 15.)}

Bull. Sci. Lab. Den. Univ., 11:250 ; 1901.

This insect has previously been recorded only from Bozeman, Montana, and Reno, Nevada (6,600 ft.). In the collections sent by Dr. Philip and Dr. H. B. Mills there are 15 specimens of both sexes from Blacktail Flat and Specimen Ridge, Yellowstone National Park, Wyoming, March 17, 1934 and Feb. 5, 1935; and several specimens from Gird's Creek, Ravalli County, Montana, November 2 and December 30, 1934 (N. L. Jellison). Mr. Lloyd (1934) recorded this species from Alaska also, but his specimens really belong to a new species (gracilis) described below. 
The hypandrium is entire and broadly triangular in outline (figure 15). The body is covered with a very short pubescence; the beak is short, about one and one-half times as long as the eye, and only half as long as the ovipositor.

Boreus nix n. sp. (Figure 7.)

Male: length of body, $3 \mathrm{~mm}$.; uniformly black except the eyes, which are either black or dark brown or both; entire body including wings covered with long, white pilosity, except pronotum, which bears two rows of very long heavy black hairs, one row along the anterior margin, the other along the posterior margin; wings with the outer margin smoothly curved, as in unicolor (see Carpenter, 1931, fig. 6d) ; hypandrium broadly triangular, deeply emarginate (figure 7 ) ; rostrum short, less than one and one-half times the length of the eye.

Female: length, $4 \mathrm{~mm}$; entire body, including wings, black and covered with long white pilosity; ovipositor one and one-half times the length of the rostrum; fore wing covering entire hind wing scar.

Holotype ( $\delta$ ) and allotype: Gird's Creek, Ravalli County, Montana, November 2, 1934, on snow (W. L. Jellison) ; both in Museum of Comparative Zoölogy.

Paratypes: 1 o with same collecting data as holotype; 2 o, 2 \& , Hamilton Heights, Ravalli County, Montana, November 15, 1931, on snow (C. B. Philip) ; all in writer's collection; 1 \& Hamilton Heights, Ravalli County, Montana, November 15, 1931, in collection of the California Academy of Sciences.

This interesting species is easily recognized by the combination of the black wings, emarginate hypandrium, and long, white pilosity. The latter is visible without magnification and gives the insect a fuzzy appearance.

Boreus pilosus n. sp. (Figure 10.)

Male: length, $3 \mathrm{~mm}$; wings light brown, genital claws and hypandrium brown, legs light brown or dark brown; eyes dark brown or black; rest of body black; entire body covered with long, yellowish-white pilosity, especially well developed on the abdominal terga; pronotum with two rows 
of very long, heavy, yellow-brown hairs; hypandrium emarginate, the notch broadly "V"-shaped; rostrum long, more than twice as long as the eye.

Female: length, 4.5-5 mm.; wings, ovipositor and legs light brown or yellow-brown; eyes dark brown or black, pronotum reddish brown; rest of body black; entire body covered with prominent yellow pilosity, which is especially long and deeply colored on abdominal terga; pronotum with the two rows of long yellow-brown hairs as in male; ovipositor short, only a little longer than the rostrum; fore wing covering hind wing scar.

Holotype ( $\hat{\delta}$ ) and allotype: Kaslo, British Columbia, December, 1932; both in Museum of Comparative Zoölogy.

Paratypes: 2 males, 8 females, all with same collecting data as holotype in Museum of Comparative Zoölogy ; and 1 female from the same lot in the California Academy of Sciences.

\section{Boreus isolatus n. sp. (Figure 11.)}

Male: length, $3.2 \mathrm{~mm}$; wings light brown, eyes brown, legs dark brown with the joints black; rest of body black; most of body covered with very fine, short, white pilosity, uniform over most of body, absent only on the anterior half of each abdominal tergum; hypandrium rather narrow, and emarginate, the notch being in the form of a " $\mathrm{V}$ "; rostrum short, scarcely longer than the eye. Female unknown.

Holotype ( $\hat{o})$ : Como Lake, Ravalli County, Montana, January 6, 1935 (W. L. Jellison) ; in Museum of Comparative Zoölogy.

Although somewhat hesitant to describe this species from the single male at hand, I believe that the characteristics of the male are so distinctive that it unquestionably represents an easily recognized species. It is the only one of the western species of Boreus which has the combination of the emarginate hypandrium and short pilosity, the other species with the emarginate hypandrium (pilosus and nix) having long pilosity over the entire body, and especially on the abdominal terga. 


\section{Boreus intermedius Lloyd}

Pan. Pacific Ent., 10:119-120; 1934.

Male: length, $3.5 \mathrm{~mm}$.; wings and legs yellow or yellowbrown, hypandrium and genitalia yellow and brown, eyes grayish brown, mottled with black, rest of body dark bronze, almost black; entire body covered with fine, short pubescence, nearly absent on abdominal terga; wings abruptly narrowed near the middle, as in californicus, but with the distal half much more slender than in that species; hypandrium entire, narrowly triangular; rostrum twice as long as the eye.

Female: wings yellow, legs yellow-brown, ovipositor brown and dark brown, eyes grayish brown; rest of body dark bronze; entire body covered with fine, short, white pilosity nearly absent on abdominal terga; fore wing completely covering hind wing scar; ovipositer scarcely (if at all) longer than the rostrum.

Holotype ( $\hat{o}$ ) and allotype: collected between Kennecott and McCarthy, Alaska, April 15, 1934; on snow; both in Washington State Museum ${ }^{5}$.

The male of this species resembles closely that of californicus, but differs in having the distal half of the wings much more slender than in that species. The female, also, approaches that of californicus but can be distinguished by the much shorter ovipositer.

\section{Boreus borealis Banks. (Figure 14.)}

N. Amer. Fauna, Bur. Biol. Surv., U.S.D.A., $46: 158 ; 1923$.

Male: length $4 \mathrm{~mm}$; wings yellow-brown; hypandrium and legs light brown and brown; eyes brown; rest of body black; with a pronounced bronze hue; abdomen above extremely shiny; short, white pilosity sparsely distributed over body, reduced on terga; pronotum without long spines; wings strongly narrowed in the proximal half; hypandrium entire; rostrum one and one-half times the length of the eye.

${ }^{5}$ After this paper had been sent to the press a pair of intermedius were forwarded to me by $\mathrm{Mr}$. Lloyd; both were collected at the type locality (April 29, 1935) and have been deposited in the Museum of Comparative Zoölogy. 
Female: length, $5 \mathrm{~mm}$.; color as in male; pilosity sparse, especially on abdomen; wing pads yellow, covering hind wing scars; ovipositer one and one-half times the length of the beak.

This rare species, of which only four specimens are known, has not been collected outside of the type locality, St. Paul Island, Bering Straits, Alaska. It closely resembles the fuscus var. of californicus, but differs in the bronze coloration and the brilliant shine of the abdomen.

Boreus californicus Packard. (Figure 13.)

Proc. Bost. Soc. Nat. Hist., 8:408; 1871.

Male: length 3.5-4 mm.; wings light yellow to light brown; eyes gray, rest of body brown, usually more or less bronze in color; body covered with fine, short, white pubescence, nearly absent from abdominal terga; fore wings abruptly narrowed at about the middle; hypandrium entire, broadly triangular; rostrum one and one-half times as long as the eye.

Female: length $5 \mathrm{~mm}$; color similar to that of the male, wing pads yellow to light brown; fine, short, white pilosity covering body, but much reduced on abdominal terga; ovipositor one and one-half times as long as the rostrum; fore wing pads covering hind scar.

A study of the specimens of californicus now at hand shows that there is much variation in the coloration of these insects, some having the body definitely brown and the wings yellow; others, the body black and the wings brown. The type specimens, all from Ft. Bidwell, Siskiyou County, California, are of the former class, with brown bodies and yellow wings in both sexes. A series of 7 specimens from Goose Lake, Siskiyou County, are somewhat similar, though the bodies are a dark brown and the wings a light brown. These seem to me to represent the typical californicus. The darker specimens have been found only in more northern regions (British Columbia, Alberta and Montana) and appear to me to deserve a varietal rank, designated here as fuscus.

Boreus californicus var. fuscus $n$. var.

Male: length, $3 \mathrm{~mm}$; wings and legs brown or even dark 
brown; eyes gray-brown; rest of body black; body covered with a fine, short, white pilosity, much reduced on abdominal terga; wings and hypandrium shaped as in typical californicus; rostrum one and one-half times as long as the eye.

Female: length, $4 \mathrm{~mm}$.; wings and legs light brown, eyes gray-brown; rest of body black; fine, white pilosity over body as in male; ovipositer one and one-half times as long as rostrum; fore wing pad covering hind wing scar.

Holotype ( $\hat{o}$ ) and allotype of var. fuscus: Kaslo, British Columbia, January 3, 1908; in the Museum of Comparative Zoölogy.

Paratypes: 1 ô, Gird's Creek, Ravalli County, Montana, November 4, 1934 (W. L. Jellison) ; 3 ô, 7 क , same data, November 2, 1934 (W. L. Jellison) ; 2 ㅇ, 2 ô, Kaslo, B. C., January 3, 1908; 4 ㅇ, 1 ô, Terrace, B. C. ; 1 ô, Sulphur Mt., Alberta, February 10; all in writer's collection.

\section{Boreus gracilis n. sp.}

Female: length, $5 \mathrm{~mm}$.; wings, legs, ovipositor very dark brown, almost black; eyes and rest of body black; white pilosity on body somewhat longer than that of californicus, but nearly absent on abdominal terga; pronotum with two rows of long, heavy, black spines; rostrum twice the length of the eye; ovipositor one and one-half times the length of the rostrum; fore wing pads small, not entirely covering the hind wing scar, the posterior half of which is visible from above. Male unknown.

Holotype ( $\%$ ) : collected between Kennecott and McCarthy, Alaska, April 15, 1934 (W. L. Lloyd); in Washington State Museum.

Paratype: 1 o, with same locality data as holotype; in Museum of Comparative Zoölogy.

The specimens on which this species is based were determined by Lloyd (1934) as unicolor Hine. They are excluded from this species, however, by the difference in the lengths of the rostrum and the ovipositor, as well as by the partially reduced fore wing pads, a characteristic which is not shared by any other of our Boreus.

\section{Boreus reductus Carp. (Figure 9.)}

Can. Ent., 65:94-95; fig. 1; 1932.

This species has previously been known only from the five 
types, collected at Kaslo and Lillooet, B. C. Five additional specimens, three males and two females, are present in the material sent to me by Dr. Philip. All were taken in Ravalli County, Montana, two at Gird's Creek (Nov. 2, 1934) and the others at Como Lake (Jan. 6, 1935) by W. L. Jellison. Since the Montana locality is almost two hundred and fifty miles south of Kaslo, the range of the species is extended considerably by the new material. These specimens have also enabled us to make a better diagnosis of the species than was possible with the type material alone. The females, of course, are readily distinguished by the complete loss of the fore wing pads. Both males and females are covered with a long, white pilosity, longer than that of any of the other species of Boreus except two of the species described above (nix and pilosus). The hypandrium of the male (figure 9) is long and slender, the sides in the distal half being nearly parallel.

\section{Boreus elegans n. sp. (Figures 8, 12.)}

Male: length, 3.5-3.8 mm.; wings and legs light brown, almost yellow; hypandrium, rostrum and pronotum reddish brown; eyes dark red; head and abdomen dark reddish brown; fine, white pilosity over body, well devcloped on the abdominal terga; pronotum with two rows of long, black spines; fore wings long and very broad, two and one-half times as long as the rostrum and broader than in any other species of the genus, the outer margins almost straight; hypandrium entire, narrowly triangular; rostrum not quite one and one-half times the length of the eyes. Female unknown.

Holotype ( $\hat{o}$ ) : Vancouver, B. C., Dec. 1930 (H. E. Hinton) ; in California Academy of Sciences.

Paratype: 1 o with same locality data as the holotype; in Museum of Comparative Zoölogy.

This is the most striking of the Nearctic species of Boreus; it is the only one of our species with a dominant reddish coloration. The wings are much like those of the eastern nivoriundus, the outer margins being quite straight, but they are much longer, being two and one-half times the 


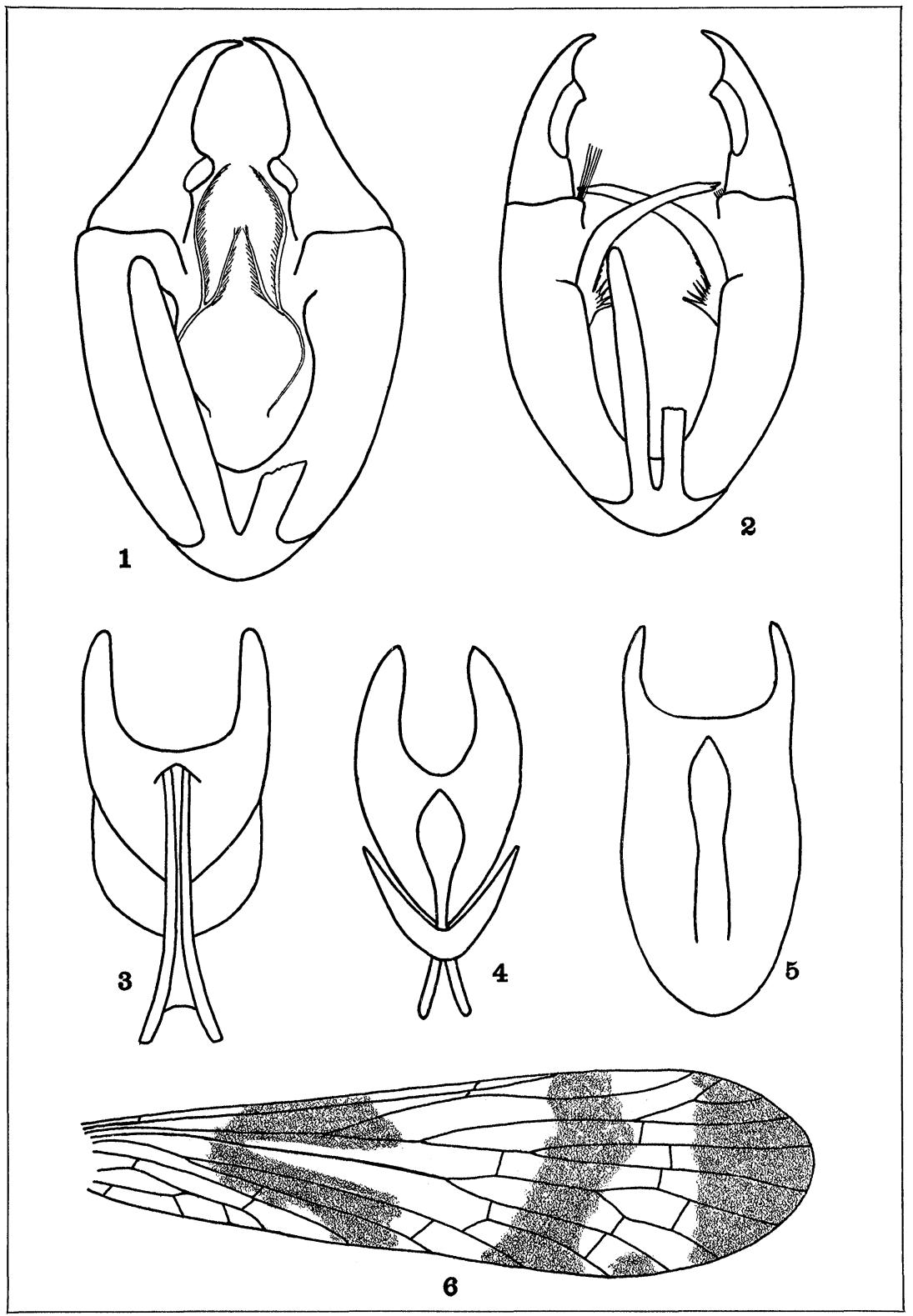

Carpenter-Mecoptera 
Psyche, 1935

Vol. 42, Plate XI.

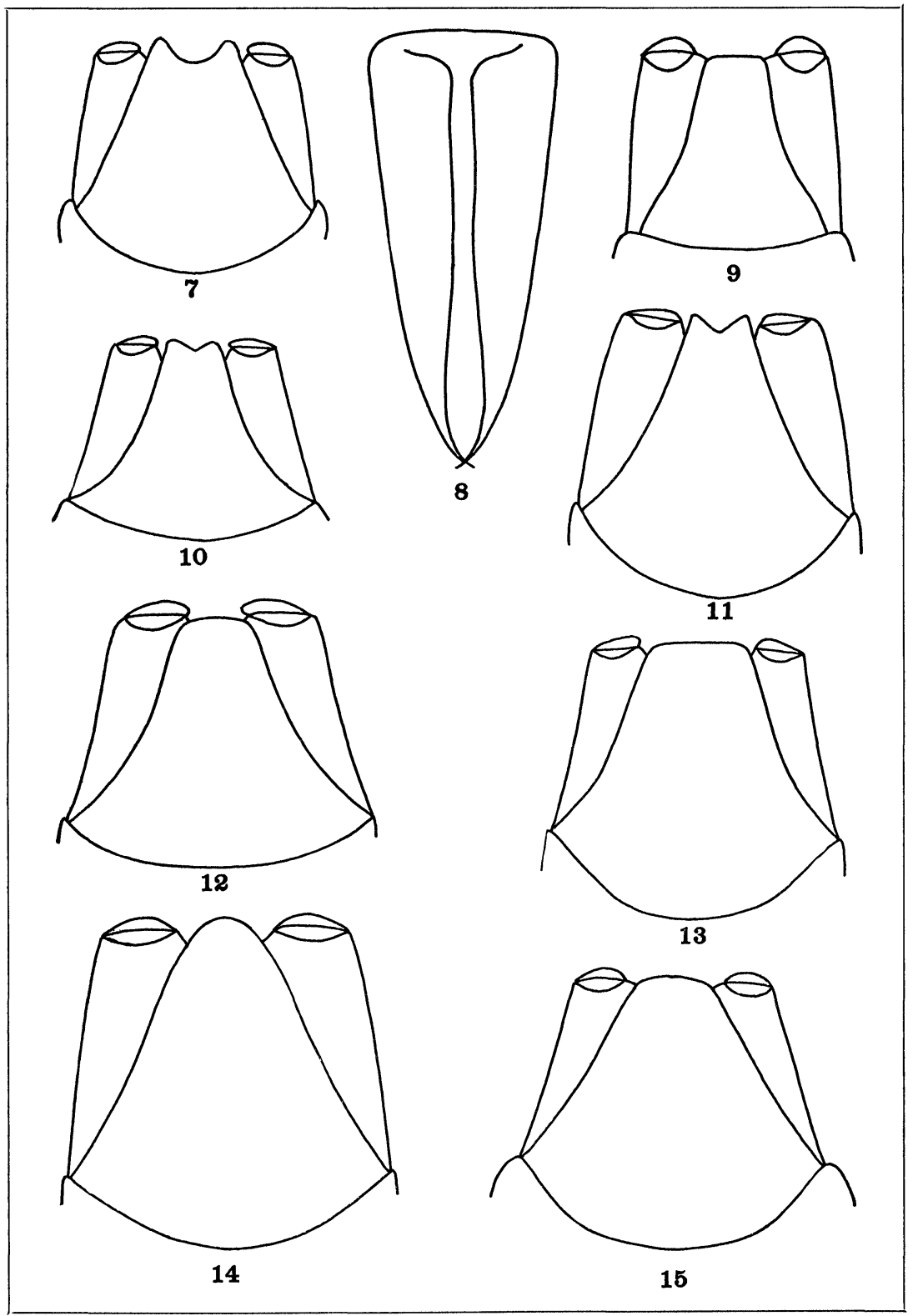

Carpenter-Mecoptera 
length of the rostrum as compared with one and one-half times in nivoriundus.

Explanation of Plates.

Plate 10.

Fig. 1. Panorpa bifida, n. sp., ô genital bulb of holotype.

Fig. 2. Panorpa flexa, n. sp., ô genital bulb of holotype.

Fig. 3. Panorpa bifida, n. sp., internal skeleton of $\$$ allotype.

Fig. 4. Panorpa speciosa Carp., internal skeleton of $q$ allotype.

Fig. 5. Panorpa insolens, n. sp., internal skeleton of $q$ holotype.

Fig. 6. Panorpa insolens, n. sp., fore wing of holotype.

\section{Plate 11.}

Fig. 7. Boreus nix, n. sp., hypandrium of $\hat{o}$ holotype.

Fig. 8. Boreus elegans, n. sp., wings of $\hat{o}$ holotype.

Fig. 9. Boreus reductus Carp., hypandrium of $\hat{\delta}$.

Fig. 10. Boreus pilosus, n. sp., hypandrium of $\hat{\delta}$ holotype.

Fig. 11. Boreus isolatus, n. sp., hypandrium of $\hat{\delta}$ holotype.

Fig. 12. Boreus elegans, n. sp., hypandrium of $\hat{\delta}$ holotype.

Fig. 13. Boreus californicus Packard, hypandrium of $\hat{\delta}$.

Fig. 14. Boreue borealis Banks, hypandrium of $\hat{\delta}$ cotype.

Fig. 15. Boreus unicolor Hine, hypandrium of $\hat{s}$. 

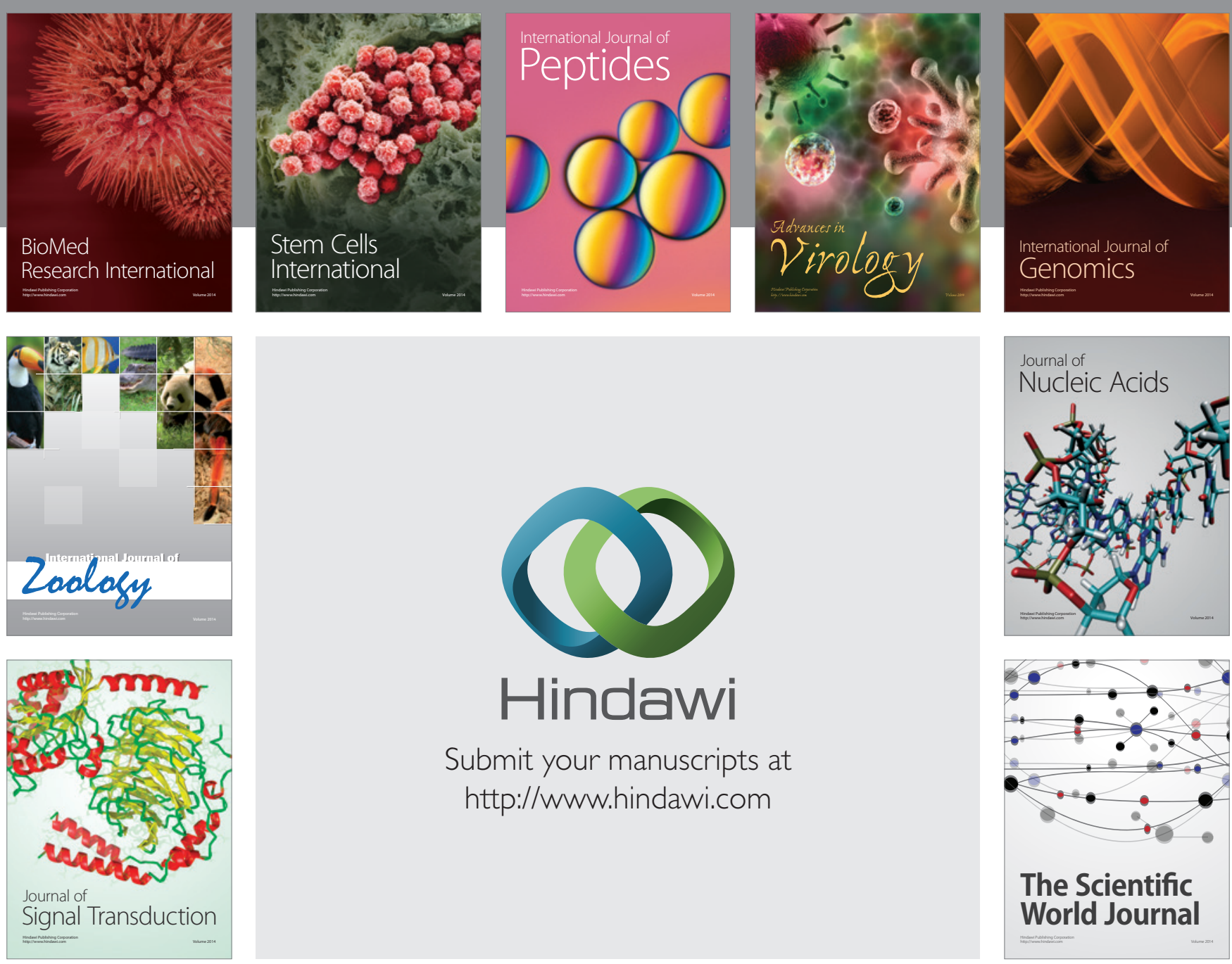

Submit your manuscripts at

http://www.hindawi.com
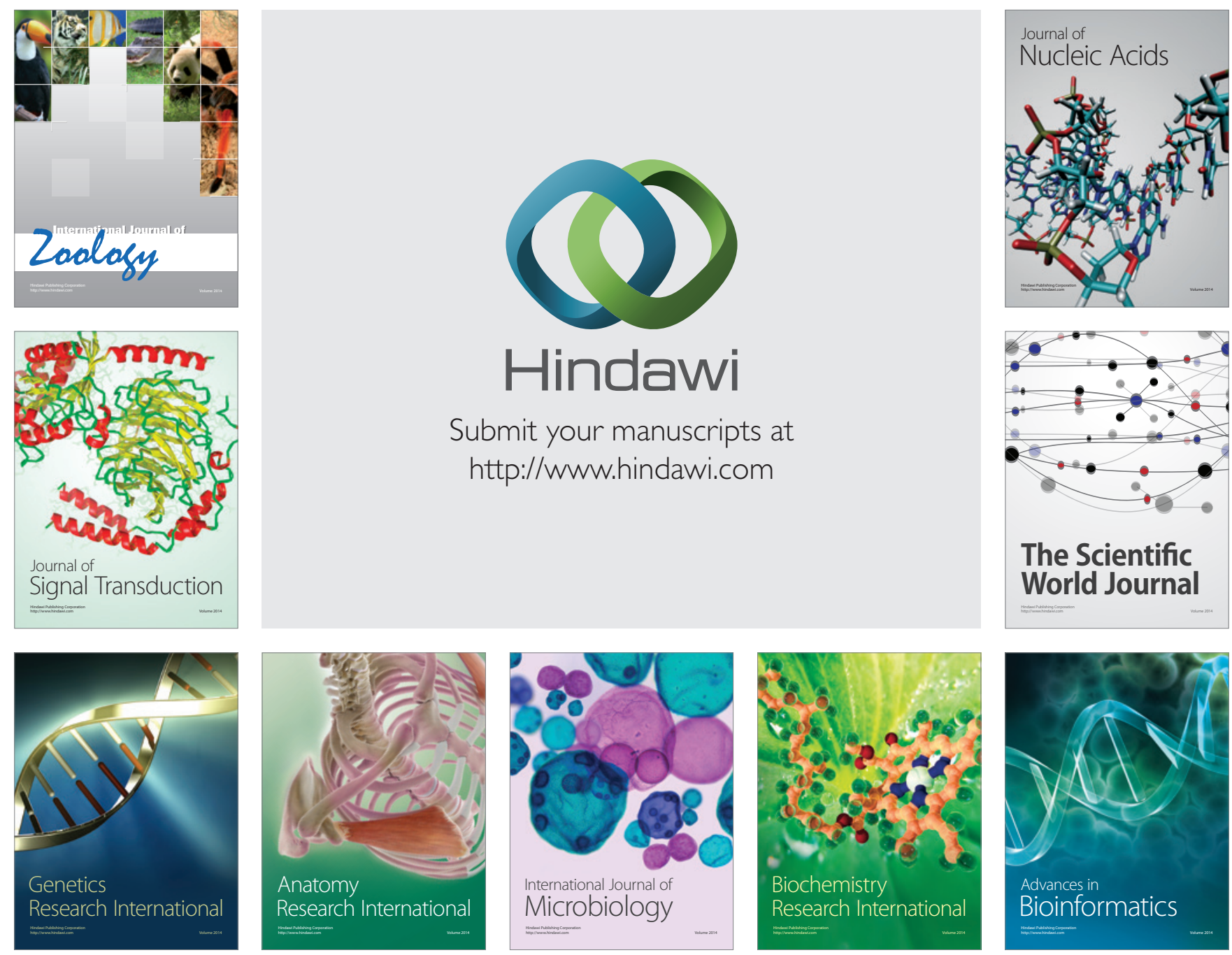

The Scientific World Journal
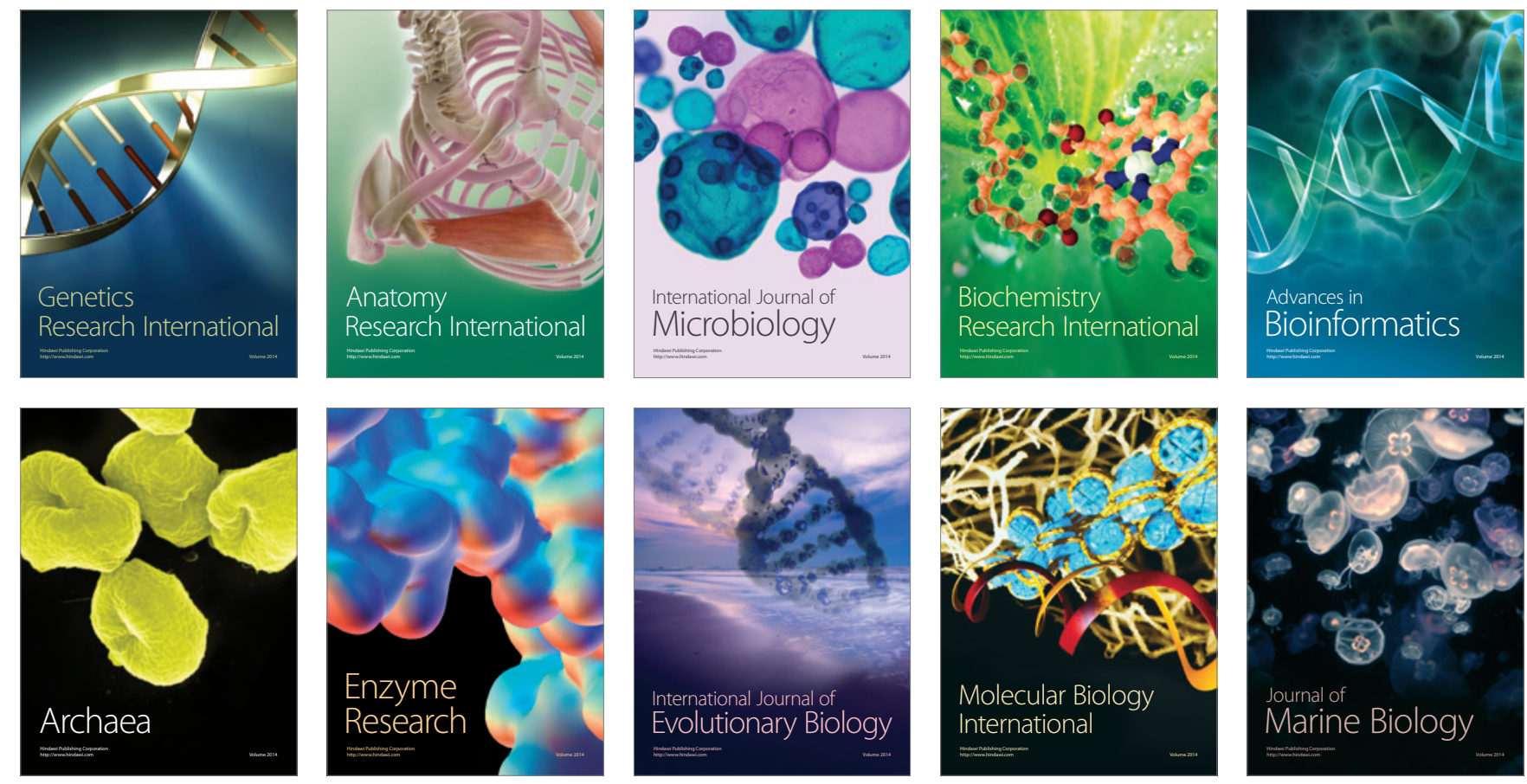